\section{TOWARDS A SUSTAINABLE EUROPEAN COMPANY LAW}

Do companies have a role beyond that of seeking profit for shareholders? Does company law have a role in furthering sustainable development? It may seem tempting, perhaps especially from a British company law perspective, to dismiss these questions out of hand. My analysis of the objectives of EU company and securities law indicates that this would be too hasty.

I started out with the hypothesis, which was substantiated during my research, that any sector of EU law is meant to contribute to the attainment of the EU's overarching objectives. In my book Towards a Sustainable European Company Law: A Normative Analysis of the Objectives of EU Law, with the Takeover Directive as a Test Case (Kluwer Law International, 2009) I therefore also analyse what the general objectives of the EU are. The goal of a sustainable development encapsulates much of the general objectives of the EU as they are set out in the Treaties.

The position of sustainable development as an overarching objective is supported and enhanced by Article 6 of the EC Treaty. Article 6 EC stipulates that the integration of environmental protection requirements must take place in all policies and activities within the Community, with the aim of achieving sustainable development. The essence of sustainable development is the search for a balance between its three dimensions: economic development, social development and environmental protection.

The core role of EU company and securities law is to promote economic development, notably through the facilitation of market integration. Its contributory role is to further sustainable development through facilitation of the integration of economic and social development and environmental protection. In practice, such integration does not take place as it should, because such a broad perspective requires moving beyond the simple market thinking which tends to dominate company and securities law debate and legislation.

The analysis of the Takeover Directive, which I use as the test case, demonstrates the problem with simple market thinking. The Directive is based on an unquestioning belief in the theory of a "market for corporate control." My book discusses the assumptions on which this simple economic theory from the 1970s is based and highlights the error of using a legal-economic theory devised in a different setting, without thorough research and reflection, as the theoretical basis for a European Directive. The analysis of the objectives of EU law also shows that "shareholder primacy", and requiring companies to take the related concept of "shareholder value" as an operating guideline, is wrong. When shareholder value - even in the "enlightened" version - is attempted used as the guideline

\section{Articles}

Mutual recognition in criminal matters in Cyprus

2

The Society of Enhanced Legal Scholars, Seven of Nine, and some regulatory challenges for future generations

Institute News

\section{Articles (cont'd)}

Usury, statutory avoidance and the Court of Chancery $1680-1800$

The European Union, international law and the Middle East peace process

Corporate social responsibility and banks

for running companies, it dilutes responsibility for company actions (even though the opposite is the intention). It also may, with its typical narrow, short-term focus, tend to work against the achievement of overarching societal goals.

An alternative approach should be taken. This should be based on a normative purpose of the company: the fulfilment of its function as an all-important component of our economies in such a way as to contribute to overarching goals of society. This is not a position against the shareholder interest or against profit as a goal for companies. However, profit should be sought within the framework of sustainable development instead of profit maximisation, allowing only for limited and even counterproductive CSR initiatives. Reversing the current perspective on the purpose of the company in this way distinguishes the alternative approach from the "enlightened" shareholder value of UK company law, with shareholder profit as the overarching goal, but where the board is to "have regard" to, for example, environmental concerns.

Through redefining the purpose of the company and the role and position of the board, the externalised environmental and societal costs of the company's production would be internalised. Thereby the goal of sustainable development, and especially its environmental dimension, could be integrated as a decisive factor in the minds of decision-makers in companies.

Implementation of such an alternative approach is the topic of the research project "Sustainable companies" at the Faculty of Law in Oslo.

\section{Beate Sjåfjell}

Postdoctoral research fellow, dr juris, Faculty of Law, Oslo (beate.sjafjell@jus.uio.no)

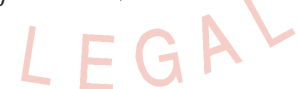

